\title{
Association between serum liver enzymes and hypertension: a cross-sectional study in Bangladeshi adults
}

\author{
Sadaqur Rahman, Shiful Islam, Tangigul Haque, Rahanuma Raihanu Kathak and Nurshad Ali ${ }^{\text {(D) }}$
}

\begin{abstract}
Background: Hypertension is a major contributing factor to cardiovascular disease and is a leading cause of death in the world. The association between hepatic enzymes and hypertension has been reported in limited studies and the findings are inconsistent; data from Bangladeshi adults are not available yet. This study was conducted to estimate the prevalence of elevated liver enzymes and evaluate the association of elevated liver enzymes with hypertension in Bangladeshi adults.

Methods: In this cross-sectional study, 302 blood samples were collected from adult participants and analyzed the serum concentrations of alanine and aspartate aminotransferase (ALT, AST), alkaline phosphatase (ALP), and $\gamma$-glutamyltransferase (GGT) and other markers related to hypertension. Hypertension was defined as resting SBP $\geq 140 \mathrm{mmHg}$ and/or DBP $\geq 90$ $\mathrm{mmHg}$. Associations between elevated liver enzymes and hypertension were evaluated by multinomial logistic regression.
\end{abstract}

Results: The mean concentrations of serum ALT, AST and GGT were significantly higher in the hypertensive group compared to the normotensive group ( $p<0.01, p<0.01$ and $p<0.001$, respectively). Overall, $49.2 \%$ of subjects in the hypertensive group and $38.1 \%$ of individuals in the normotensive group had at least one or more elevated liver enzymes. The prevalence of elevated ALT, AST, and GGT was significantly higher among participants in the hypertensive group compared to the normotensive group ( $p<0.01, p<0.01$ and $p<0.001$, respectively). An increasing trend for elevated liver enzymes was observed with increasing blood pressure. Serum ALT and GGT showed an independent relationship with hypertension.

Conclusions: The prevalence of elevated liver enzymes was higher in hypertensive individuals. Increased serum ALT and GGT activities were positively associated with hypertension in Bangladeshi adults.

Keywords: Liver enzymes, Blood pressure, Prevalence, Hypertension, Bangladeshi adults

\section{Background}

Hypertension is a major contributing factor for cardiovascular disease (CVD) and one of the leading causes of death in the world $[1,2]$. The world prevalence of hypertension was $26 \%$ in 2000 which is projected to be increased by $29.2 \%$ in 2025 [3]. The incidence of hypertension is increasing in developing countries along with developed countries

\footnotetext{
* Correspondence: nur_rubd@yahoo.com; nali-bmb@sust.edu Department of Biochemistry and Molecular Biology, Shahjalal University of Science and Technology, Sylhet 3114, Bangladesh
}

[4]. In the Asian region, hypertension has become a significant concern affecting over 35\% of the adults and the countries especially in South-East Asia are particularly facing the increasing burden of hypertension [5, 6]. The incidence of hypertension in Bangladesh has increased rapidly in the past years $[7,8]$. Hypertension and its complications are responsible for a significant portion of the death of the Bangladeshi population and a burden for the national economy. Early diagnosis and management of increased blood pressure before hypertension development may be

(c) The Author(s). 2020 Open Access This article is licensed under a Creative Commons Attribution 4.0 International License, which permits use, sharing, adaptation, distribution and reproduction in any medium or format, as long as you give appropriate credit to the original author(s) and the source, provide a link to the Creative Commons licence, and indicate if changes were made. The images or other third party material in this article are included in the article's Creative Commons licence, unless indicated otherwise in a credit line to the material. If material is not included in the article's Creative Commons licence and your intended use is not permitted by statutory regulation or exceeds the permitted use, you will need to obtain permission directly from the copyright holder. To view a copy of this licence, visit http://creativecommons.org/licenses/by/4.0/ The Creative Commons Public Domain Dedication waiver (http://creativecommons.org/publicdomain/zero/1.0/) applies to the data made available in this article, unless otherwise stated in a credit line to the data. 
cost-benefit in terms of reducing premature morbidity and mortality in general people [9].

The interrelationship between liver dysfunction and the development of hypertension is being increasingly recognized. The liver is a vital organ in metabolism that plays numerous roles included synthesis, degradation, storage, and biotransformation of bio-molecules in the human body [10]. The liver enzymes alanine and aspartate aminotransferase (ALT and AST), $\gamma$-glutamyltransferase (GGT), and alkaline phosphatase (ALP) have been widely used as a good marker of liver health [11]. The elevated levels of ALT, AST, and GGT reflect an excess fat deposition in the liver, a condition termed as nonalcoholic fatty liver disease (NAFLD). These enzymes are suggested to have substantial clinical and epidemiological significance as convenient surrogate markers of NAFLD and related liver dysfunction [12, 13]. Some epidemiological studies have demonstrated an association of ALT and GGT with metabolic syndrome, CVD and type 2 diabetes [14-17]. In previous studies, CVD has been demonstrated as a leading cause of death in NAFLD, with higher rates coinciding with increased liver-related mortality throughout followup investigations [18-20].

An association between higher serum GGT levels and hypertension has been reported in some longitudinal and cross-sectional studies [15, 21-24]. However, most of the previous studies assessed the relationship that included only one or two hepatic enzymes and their findings were inconsistent. The epidemiological data concerning the extent of elevated liver enzymes in the Bangladeshi hypertensive individuals are not available yet. To address these issues, we conducted a cross-sectional study to examine the association of all four liver enzymes with hypertension in Bangladeshi adults.

\section{Methods}

\section{Study participants and area}

This cross-sectional study was conducted between October 2017 and September 2018 at the Department of Biochemistry and Molecular Biology, Shahjalal University of Science and Technology, Sylhet, Bangladesh. More than 350 participants aged above 18 years were invited randomly to take part in the study, among them 302 subjects agreed to participate. The participants included general adults from Sylhet city regions, academic and non-academic staffs and university adult students. The inclusion criteria were: both gender, aged above 18 years, free from severe chronic illness and willing to participate. Exclusion criteria: participants with a history of hepatotoxic drugs intake, alcohol intake (alcohol consumption is generally prohibited in Bangladesh from religion restriction), and severe chronic or acute evidence of liver diseases reported by participants were excluded from the study. Written informed consent obtained from all participants before inclusion in the study. This study was approved by the internal Ethics Committee at the Department of Biochemistry and Molecular Biology of Shahjalal University of Science and Technology. All steps in the method section were conducted out following the relevant guidelines and regulations.

\section{Anthropometric and blood pressure data}

Trained personnel measured the anthropometric and blood pressure (BP) data and recorded in the questionnaire form according to the standard procedure described elsewhere [25-27]. An individual's body weight and height were measured to calculate the BMI $\left(\mathrm{kg} / \mathrm{m}^{2}\right)$. Using a digital BP machine (Omron M10, Omron Corporation, Tokyo, Japan), individuals BP was measured on the left arm in a sitting position after the participant rested for 10 min. The first BP measurement was discarded to avoid possible effects of anxiety, and the mean value of the second and third measurements was count for systolic blood pressure (SBP) and diastolic blood pressure (DBP). The participants were requested to avoid coffee, tea and smoking for $30 \mathrm{~min}$ before BP measurements. Physical activity was categorized as low, medium and adequate based on participation in any activities such as jogging, bicycling, swimming or daily sports. The questionnaire also asked about the smoking status of the participants (yes or no). Individual food habits and brief lifestyle information were also recorded in the questionnaire form.

\section{Sample collection and biochemical analysis}

The participants were at least $10-12 \mathrm{~h}$ of overnight fast before providing the blood samples. From each participant, about $5 \mathrm{ml}$ of the venous blood was drawn in a plain dry vacutainer tube using disposable syringes. Serum was separated and stored at $-80^{\circ} \mathrm{C}$ in the laboratory until biomarkers analysis. Serum concentrations of glucose, total cholesterol (TC), triglycerides (TG), albumin and total protein were measured by colorimetric methods. Activities of serum liver enzymes ALT, AST, GGT and ALP were measured by kinetic methods. All measurements were done using commercially available diagnostic kits (Human Diagnostic, Germany, except GGT from Vitro Scient, Egypt) with a biochemistry analyzer (Humalyzer 3000, USA).

\section{Diagnostic criteria}

The liver enzymes at elevated levels were defined as one or more measurement of: AST $>35 \mathrm{U} / \mathrm{L}$ in men/ $>31 \mathrm{U} / \mathrm{L}$ in women, $\mathrm{ALT}>45 \mathrm{U} / \mathrm{L}$ in men/ $>34 \mathrm{U} / \mathrm{L}$ in women, GGT $>55 \mathrm{U} / \mathrm{L}$ in men/ $>38 \mathrm{U} / \mathrm{L}$ in women [28] and ALP $>128$ $\mathrm{U} / \mathrm{L}$ in men/ > $98 \mathrm{U} / \mathrm{L}$ in women [29]. Hypertension (stage 2) was defined as resting $\mathrm{SBP} \geq 140 \mathrm{mmHg}$ and/or $\mathrm{DBP} \geq$ $90 \mathrm{mmHg}$ or by treatment for hypertension [30, 31]. 


\section{Statistical data analysis}

Baseline data are expressed as mean \pm standard deviation, whereas, the categorical data are mentioned as percentages. Pearson's correlation coefficient test (two-tailed) was performed to examine the correlation between hepatic markers and baseline variables. The differences between anthropometric and baseline characteristics in the gender and case-control groups were done by independent sample t-test. Associations between liver enzymes and hypertension were evaluated by multinomial logistic regression analysis. A $p$-value of $<0.05$ was set statistically significant. Statistical data analyses were done using IBM SPSS software (version 23).

\section{Results}

\section{Baseline characteristics of the study cohort}

The baseline characteristics of the study subjects are presented in Table 1. Out of 302, 198 were normotensive (152 male and 46 female) and 104 were hypertensive individuals (74 male and 30 female). The average age for normotensive and hypertensive subjects was $37.2 \pm 14.6$ and $44.0 \pm 15.2$ years, respectively. The participants in the hypertensive group had a significantly higher mean

Table 1 Baseline characteristics of the hypertensive and normotensive participants

\begin{tabular}{|c|c|c|c|}
\hline & Normotensive & Hypertensive & $p$-value \\
\hline N & 198 & 104 & - \\
\hline Male/female & $152 / 46$ & $74 / 30$ & - \\
\hline Age (yrs) & $37.2 \pm 14.6$ & $44.0 \pm 15.2$ & 0.000 \\
\hline BMI $\left(\mathrm{kg} / \mathrm{m}^{2}\right)$ & $23.3 \pm 3.5$ & $25.7 \pm 3.7$ & 0.000 \\
\hline $\mathrm{SBP}(\mathrm{mm} \mathrm{Hg})$ & $121.2 \pm 9.5$ & $145.7 \pm 16.5$ & 0.000 \\
\hline $\mathrm{DBP}(\mathrm{mm} \mathrm{Hg})$ & $77.1 \pm 6.2$ & $91.4 \pm 7.4$ & 0.000 \\
\hline $\operatorname{ALT}(\mathrm{U} / \mathrm{I})$ & $26.0 \pm 13.7$ & $33.7 \pm 19.5$ & 0.006 \\
\hline AST (U/l) & $25.7 \pm 8.3$ & $31.2 \pm 13.5$ & 0.003 \\
\hline GGT (U/I) & $20.4 \pm 9.5$ & $40.8 \pm 33.5$ & 0.000 \\
\hline ALP (U/I) & $96.0 \pm 29.6$ & $94.8 \pm 36.9$ & 0.830 \\
\hline Glucose (mg/dl) & $102.8 \pm 28.7$ & $109.2 \pm 24.2$ & 0.323 \\
\hline TG (mg/dl) & $128.4 \pm 60.0$ & $221.1 \pm 133.7$ & 0.000 \\
\hline TC (mg/dl) & $188.7 \pm 69.6$ & $259.3 \pm 100.6$ & 0.000 \\
\hline Serum albumin (mg/dl) & $48.9 \pm 10.8$ & $50.7 \pm 19.9$ & 0.489 \\
\hline Total Protein (mg/dl) & $78.6 \pm 28.0$ & $80.6 \pm 27.2$ & 0.650 \\
\hline Smoking status (\%) & & & 0.328 \\
\hline Yes & 22.9 & 16.5 & \\
\hline No & 77.1 & 83.5 & \\
\hline Physical activity (\%) & & & 0.476 \\
\hline High & 7.1 & 5.1 & \\
\hline Moderate & 67.1 & 77.2 & \\
\hline Low & 25.7 & 17.7 & \\
\hline
\end{tabular}

Data are presented as mean \pm SD. $P$-values are obtained from Independent sample t-test
BMI $\left(25.7 \pm 3.7 \mathrm{~kg} / \mathrm{m}^{2}\right)$ than the participants in the normotensive $\left(23.3 \pm 3.5 \mathrm{~kg} / \mathrm{m}^{2}\right)$ group $(p<0.001)$. The mean concentrations of ALT, AST, GGT were significantly higher in the hypertensive group compared to the normotensive group $(p<0.01, p<0.01$ and $p<0.001$, respectively). A variation has been observed for liver enzymes among male-females in both normotensive and hypertensive groups (Fig. 1). Male participants in the normotensive group had higher mean concentrations of ALT and GGT whereas ALP concentration was higher in females. In the hypertensive group, mean GGT and ALP concentrations were higher in males and AST was higher in females but no differences were observed for ALT concentration between male and female participants. An increasing trend of liver enzymes concentrations was observed in the BP groups (Fig. 2). The mean levels of serum TC, TG and glucose were also significantly higher in the hypertensive group $(p<0.001)$. In both groups, no significant differences were found for serum albumin, total protein, smoking status, physical activity and raw salt intake.

\section{Prevalence of elevated liver enzymes}

The prevalence of elevated liver enzymes in both groups are presented in Table 2. Overall, 49.2\% of participants in hypertensive and $38.1 \%$ participant's in the normotensive group had at least one or more elevated liver enzymes. The prevalence rate was significantly higher in hypertensive group (ALT 20.6\% vs 13.8\%, $p<0.01$; AST $27.5 \%$ vs $17.7 \%, p<0.01$; GGT $19.6 \%$ vs $2.3 \%, p<0.001$ and ALP $20.6 \%$ vs $16.9 \%, p>0.05)$ compared to the normotensive group (Table 2). In the hypertensive group, the most common liver enzymes abnormalities were found in female participants, whereas, in the normotensive group, a variation was observed between male-female groups.

\section{Correlation between liver enzymes and hypertensive risk factors}

The correlations of liver enzymes with common risk factors of hypertension development are summarized in Table 3. AST and GGT showed a significant association with the age of the participants $(p<0.05$ and $p<0.001$, respectively). All liver enzymes except ALP showed a significant association with both SBP and DBP. ALP and GGT showed a significant positive association with glucose concentration. ALT, AST and GGT were significantly correlated with TG, where AST and GGT were correlated with TC. The magnitude of these correlations was stronger for AST and GGT. All liver enzymes showed a negative association with serum albumin, whereas, ALT and GGT showed a significant positive association with serum total protein. 

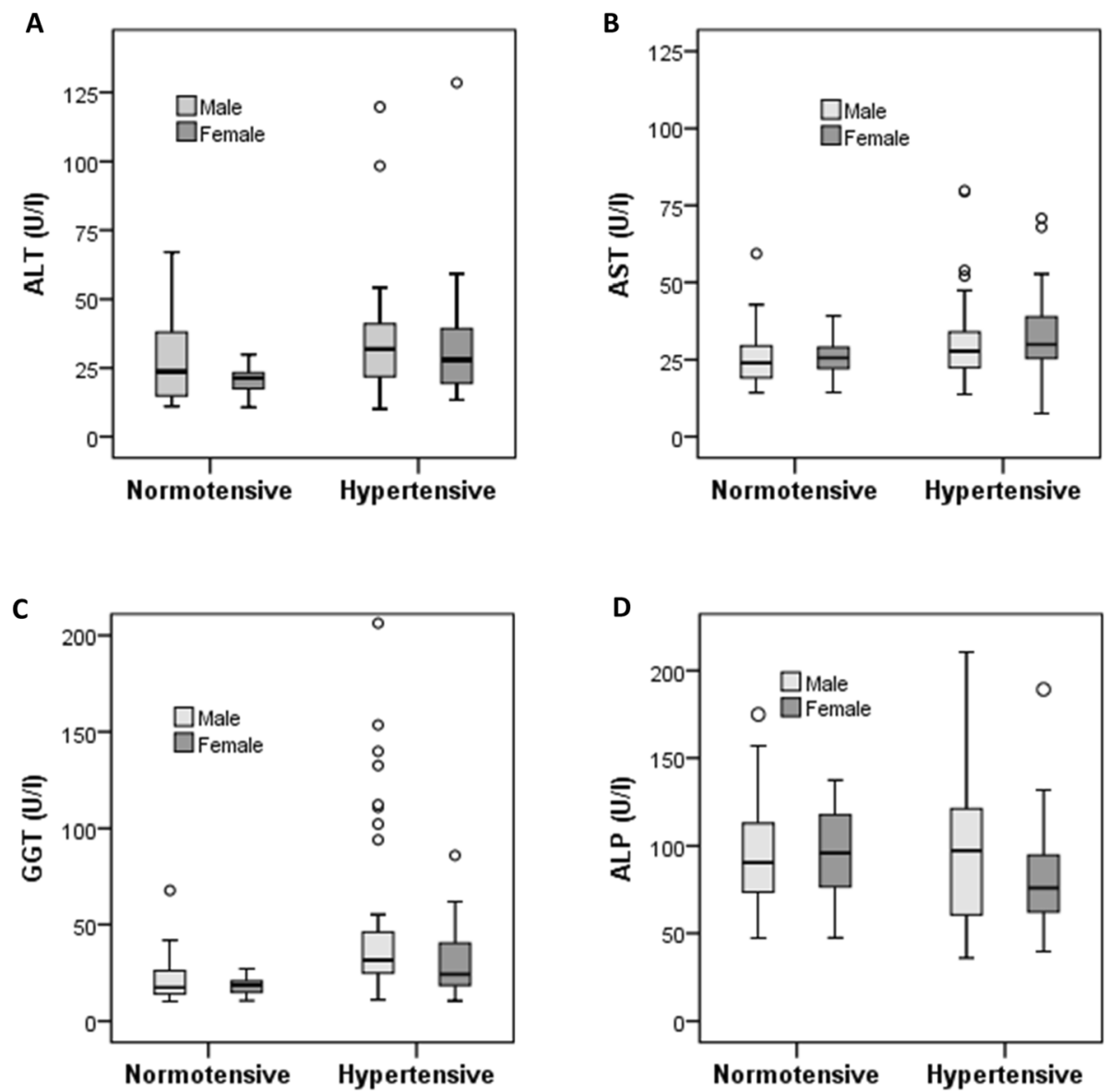

Fig. 1 Levels of ALT (a), AST (b), GGT (c) and ALP (d) in normotensive and hypertensive group by gender. The scale in the Y-axis is not similar for all liver enzymes. The box represents the central data of distribution where upper and lower limits of the box indicate 25th and 75th percentiles (first quartile or Q1 and third quartile or Q3, respectively) and the median value is presented as a line inside the box. In the box plot outlier values are more than 1.5 times the interquartile range (IQR) and the Q1 and Q3, respectively"

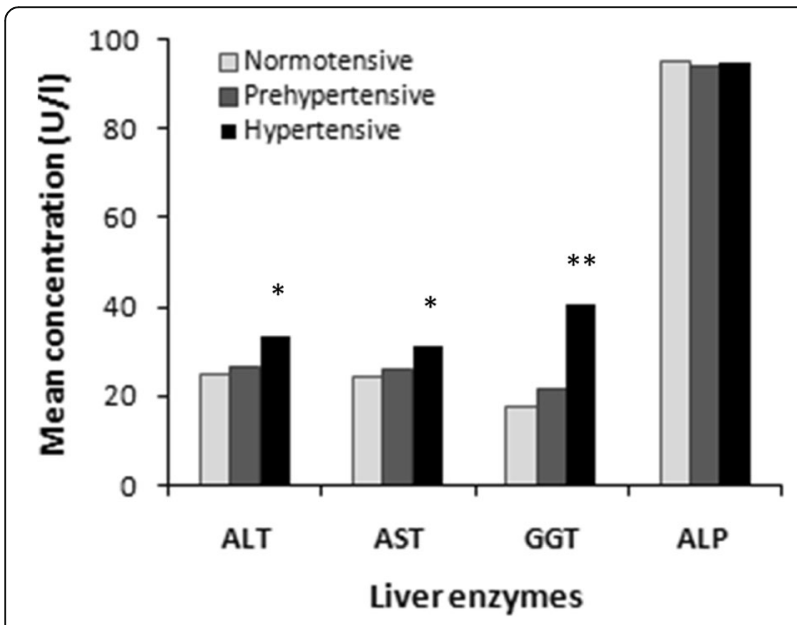

Fig. 2 Levels liver enzymes in normotensive, prehypertensive and hypertensive group. ${ }^{*} P<0.01$ and ${ }^{* *} P<0.001$ when compared to normotensive group
Association of liver enzymes with hypertension

Table 4 shows the risk of hypertension increased along with the higher concentrations of ALT and GGT, which remained significant even in a multivariate-adjusted logistic model. In model 1, age and sex were adjusted and ALT and GGT showed significant association with hypertension. In model 2, BMI, fasting blood glucose, TG and TC were adjusted, in model 3, further serum albumin and total protein were adjusted and in model 4, additionally smoking status and physical activity were adjusted. In all models, ALT and GGT showed a significant positive association with hypertension $(p<0.01$ for model 1 and $p<0.05$ for model 2-4).

\section{Discussion}

The present study demonstrates that serum ALT and GGT are positively associated with the prevalence of hypertension. This study provides the first information on the association between liver enzymes and hypertension among Bangladeshi adults. 
Table 2 Prevalence of elevated liver enzymes in normotensive and hypertensive group by gender

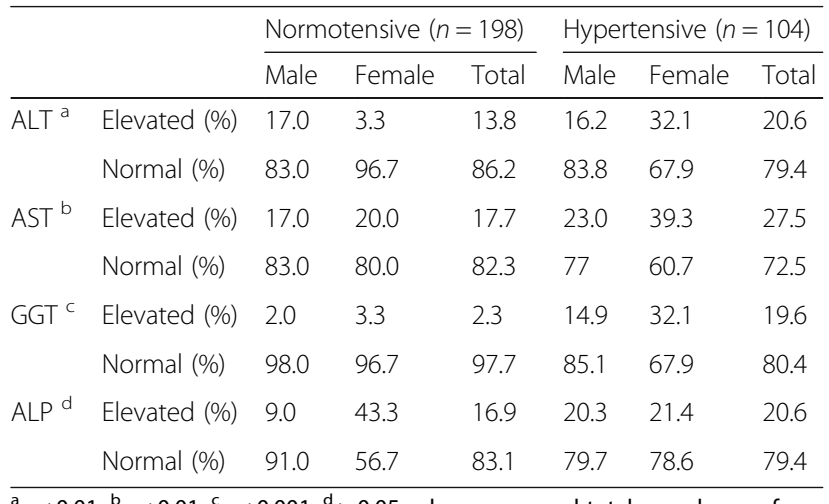

${ }^{\mathrm{a}} p<0.01,{ }^{\mathrm{b}} p<0.01,{ }^{\mathrm{c}} p<0.001,{ }^{\mathrm{d}}>0.05$, when compared total prevalence of elevated liver enzymes between normotensive and hypertensive groups

In the present study, the prevalence of elevated hepatic enzymes (ALT, AST, and GGT) was significantly higher among hypertensive individuals. The serum level of ALT was about one and a half and GGT was two times higher in hypertensive subjects than in the normotensive individuals. When age was taken into account, elevated GGT levels were more likely to be found in persons at high risk of hypertension. A high prevalence of elevated levels of ALT and GGT demonstrated a higher risk for hypertensive females and males than their normotensive counterparts. A similar result was found in a previous study that reported a high prevalence of elevated ALT in the hypertensive group compared to the normotensive group [9].

In our study, both SBP and DBP were significantly associated with ALT, AST and GGT. However, in regression analysis, only ALT and GGT were significantly associated with hypertension even after adjustment of potential confounders. Our results for GGT are in agreement with the findings of previous prospective studies [15, 21-24, 32] that showed baseline serum GGT was an independent risk factor for hypertension development. We also observed an increasing trend for the mean levels of ALT, AST and
GGT in the prehypertension and hypertensive group compared to the normotensive group. Higher levels of GGT were previously reported in prehypertensive Korean, Japanese, Chinese, and US adults [33-36].

In the present study, serum ALT showed an independent association with hypertension in Bangladeshi adults. A similar finding was observed in a previous study that reported ALT as a potential indicator of hypertension in Chinese senior adults [9]. There is no simple explanation for why a serum ALT showed an independent association with hypertension in the Bangladeshi population. One possibility may be that hypertensive individuals develop NAFLD after a long period of elevated blood pressure [37]. The postulated mechanism could be that increased blood pressure activates pro-inflammatory responses such as TNF- $\alpha$ and interleukin adiponectin and leptin that contribute to hepatotoxicity [38]. This needs further investigation. Serum AST and ALP did not show a significant association with hypertension in the present investigation. Up to now, a very limited number of studies evaluated the association of AST and ALP with hypertension and their findings are inconsistent [39, 40]. Moreover, a wide variation has been observed on the prevalence of elevated liver enzymes in the previous studies. Different reference values, age range, ethnicity, and demography might be considerable factors for the observed variations of these studies.

The biological mechanism underlying the relationships between hepatic enzymes and hypertension remains unclear. Study evidence suggests a link of NAFLD with CVD [21]. Some cross-sectional studies showed a higher incidence of NAFLD in hypertensive individuals, as compared with those with normal BP [37, 41]. A recent follow-up study showed that fatty liver development is related to hypertension in Korean adults [42]. On the other hand, a potential mechanism for the link between GGT and hypertension might be related to oxidative stress and the role of cellular GGT in the catabolism of extracellular antioxidant glutathione [21, 35]. Also, it has been reported

Table 3 Correlation between liver enzymes and baseline characteristics of the participants

\begin{tabular}{|c|c|c|c|c|c|c|c|c|}
\hline & \multicolumn{2}{|l|}{ ALT } & \multicolumn{2}{|l|}{ AST } & \multicolumn{2}{|l|}{ ALP } & \multicolumn{2}{|l|}{ GGT } \\
\hline & Correlation $(r)$ & $p$-value & Correlation $(r)$ & $p$-value & Correlation (r) & $p$-value & Correlation $(r)$ & $p$-value \\
\hline Age & 0.073 & 0.482 & 0.158 & 0.049 & 0.108 & 0.189 & 0.298 & 0.015 \\
\hline BMI & 0.149 & 0.064 & 0.189 & 0.019 & 0.078 & 0.459 & 0.132 & 0.104 \\
\hline SBP & 0.157 & 0.049 & 0.161 & 0.045 & 0.058 & 0.624 & 0.192 & 0.018 \\
\hline DBP & 0.222 & 0.005 & 0.222 & 0.005 & 0.049 & 0.642 & 0.246 & 0.002 \\
\hline Glucose & 0.068 & 0.517 & 0.063 & 0.433 & 0.177 & 0.029 & 0.257 & 0.001 \\
\hline TG & 0.300 & 0.000 & 0.381 & 0.000 & 0.081 & 0.350 & 0.530 & 0.000 \\
\hline TC & 0.113 & 0.186 & 0.281 & 0.001 & 0.056 & 0.617 & 0.225 & 0.009 \\
\hline Albumin & -0.035 & 0.663 & -0.157 & 0.052 & -0.041 & 0.621 & -0.095 & 0.244 \\
\hline Total protein & 0.258 & 0.002 & 0.143 & 0.083 & 0.110 & 0.197 & 0.236 & 0.004 \\
\hline
\end{tabular}

Correlation was analyzed using Pearson's Correlation Coefficient test (two-tailed) 
Table 4 Association of liver enzymes with hypertension

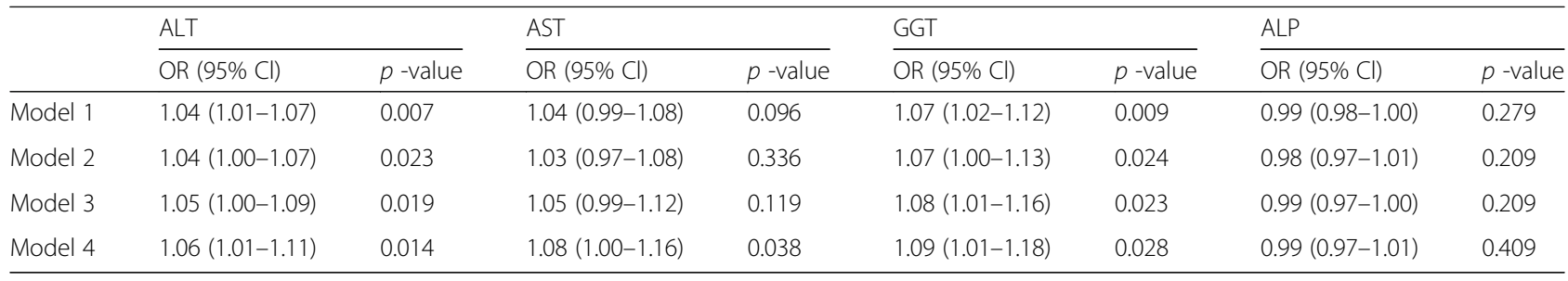

Model 1: adjusted for age and sex

Model 2: Model 1 plus, BMI, glucose, TG and TC

Model 3: Model 2 plus albumin and total protein

Model 4: Model 3 plus smoking status and physical activity

that cellular GGT may be related to reactive oxygen species production in the presence of transition metals [43]. In parallel, oxidative stress is documented to be associated with hypertension [44] and antioxidant enzyme genes polymorphisms, including few of the glutathione-Stransferase genes, have been reported to be correlated with the risk of hypertension in the general adults $[45,46]$. Further investigations are required to confirm the postulated mechanisms between elevated liver enzymes and incident hypertension in the general population.

The strength of the present study included an adjustment for well-known hypertensive risk factors including age, BMI, lipids, smoking and physical activities to examine the relationships. However, some limitations of the present study should be considered. First, we measured the hepatic enzymes at baseline level which may not represent the long-term profile. The second limitation of the present study is a small sample size. Third, the cross-sectional nature of the study may preclude any casual relationship between hepatic enzymes and hypertension. Moreover, hepatitis B and C infection were not measured among the participants that may have effects on elevated hepatic enzymes.

\section{Conclusion}

A high prevalence of elevated liver enzymes was found in hypertensive individuals and this elevation was higher in females than in the males. An increasing trend of elevated liver enzymes was found in the prehypertensive and hypertensive group compared to the normotensive group. Serum ALT and GGT activities were positively associated with the prevalence of hypertension in Bangladeshi adults. Results of this study suggest that monitoring of ALT, GGT levels could help in the diagnosis of hypertension. Prospective large scale studies are needed to investigate the underlying mechanisms between liver enzymes and the incidence of hypertension in the general population.

\section{Abbreviations}

BMI: Body mass index; TC: Total cholesterol; TG: Triglycerides

\section{Acknowledgments}

The authors wish to thank health technicians and laboratory staff for their help in sample and data collection. The authors are grateful to all participants for their participation in this study. This work did not receive any external grants. It was partly supported by a small grant as internal.

\section{Authors' contributions}

SR did the experiment, analyzed the data and drafted the manuscript. SI, TH and RRK helped in sample analysis and contributed to analyzing the results. NA played a major role in the conception and design of the study, critical interpretation of the data, wrote and revised the manuscript. All authors read the manuscript and approved the final version.

\section{Funding}

This study did not receive any external funding.

\section{Availability of data and materials}

The datasets used and analyzed during the present study are available from the corresponding author on reasonable request.

\section{Ethics approval and consent to participate}

This study was approved by the Internal Ethics Committee of the Department of Biochemistry and Molecular Biology, Shahjalal University of Science and Technology, Sylhet 3114, Bangladesh. All participants were informed about the study and they gave their written consent before inclusion in the study.

\section{Consent for publication}

Not applicable.

\section{Competing interests}

The authors declare that they have no competing interests.

Received: 2 July 2019 Accepted: 2 March 2020

Published online: 11 March 2020

\section{References}

1. Kannel WB. Hypertensive risk assessment: cardiovascular risk factors and hypertension. J Clin Hypertens Greenwich. 2004;6:393-9.

2. Kearney PM, Whelton M, Reynolds K, Whelton PK, He J. Worldwide prevalence of hypertension: a systematic review. J Hypertens. 2004;22:11.

3. Lim SS, Vos T, Flaxman AD, Danaei G, Shibuya K, Adair-Rohani H, et al. A comparative risk assessment of burden of disease and injury attributable to 67 risk factors and risk factor clusters in 21 regions, 1990-2010: a systematic analysis for the global burden of disease study 2010. Lancet. 2012;380:2224-60.

4. Alwan A. Global status report on noncommunicable diseases 2010: World Health Organization; 2011.

5. Neupane D, McLachlan CS, Sharma R, Gyawali B, Khanal V, Mishra SR, et al. Prevalence of hypertension in member countries of South Asian Association for Regional Cooperation (SAARC): systematic review and meta-analysis. Medicine (Baltimore). 2014;93:e74.

6. Singh RB, Suh IL, Singh VP, Chaithiraphan S, Laothavorn P, Sy RG, et al. Hypertension and stroke in Asia: prevalence, control and strategies in developing countries for prevention. J Hum Hypertens. 2000;14:749-63. 
7. Ali N, Mahmood S, Manirujjaman M, Perveen R, Al Nahid A, Ahmed S, et al. Hypertension prevalence and influence of basal metabolic rate on blood pressure among adult students in Bangladesh. BMC Public Health. 2017;18:58

8. Chowdhury MAB, Uddin MJ, Haque MR, Ibrahimou B. Hypertension among adults in Bangladesh: evidence from a national cross-sectional survey. BMC Cardiovasc Disord. 2016;16:22.

9. Hong X, Wongtongkam N, Ward PR, Xiao S, Wang S, Peng Q, et al. An association of serum ALT with elevated blood pressure in senior adults: a case-control study. Clin Exp Hypertens N Y N 1993. 2016:38:691-5.

10. Corless JK, Middleton HM. Normal liver function: a basis for understanding hepatic disease. Arch Intern Med. 1983;143:2291-4.

11. Hanley AJG, Williams K, Festa A, Wagenknecht LE, D'Agostino RB, Kempf J, et al. Elevations in markers of liver injury and risk of type 2 diabetes: the insulin resistance atherosclerosis study. Diabetes. 2004;53:2623-32.

12. Clark JM, Brancati FL, Diehl AM. The prevalence and etiology of elevated aminotransferase levels in the United States. Am J Gastroenterol. 2003;98:960-7.

13. Clark JM, Diehl AM. Nonalcoholic fatty liver disease: an underrecognized cause of cryptogenic cirrhosis. JAMA. 2003;289:3000.

14. Jiang $\mathrm{S}$, Jiang $\mathrm{D}$, Tao $Y$. Role of gamma-glutamyltransferase in cardiovascular diseases. Exp Clin Cardiol. 2013;18:53-6.

15. Lee D-H, Jacobs DR, Gross M, Kiefe Cl, Roseman J, Lewis CE, et al. Gammaglutamyltransferase is a predictor of incident diabetes and hypertension: the coronary artery risk development in young adults (CARDIA) study. Clin Chem. 2003:49:1358-66.

16. Nannipieri M, Gonzales C, Baldi S, Posadas R, Williams K, Haffner SM, et al. Liver enzymes, the metabolic syndrome, and incident diabetes: the Mexico City diabetes study. Diabetes Care. 2005;28:1757-62.

17. Sattar N, Scherbakova O, Ford I, O'Reilly DSJ, Stanley A, Forrest E, et al. Elevated alanine aminotransferase predicts new-onset type 2 diabetes independently of classical risk factors, metabolic syndrome, and C-reactive protein in the west of Scotland coronary prevention study. Diabetes. 2004 53:2855-60.

18. Adams LA, Harmsen S, St Sauver JL, Charatcharoenwitthaya P, Enders FB, Therneau $T$, et al. Nonalcoholic fatty liver disease increases risk of death among patients with diabetes: a community-based cohort study. Am J Gastroenterol. 2010;105:1567-73.

19. Ekstedt M, Franzén LE, Mathiesen UL, Thorelius L, Holmqvist M, Bodemar G, et al. Long-term follow-up of patients with NAFLD and elevated liver enzymes. Hepatol Baltim Md. 2006;44:865-73.

20. Ong JP, Pitts A, Younossi ZM. Increased overall mortality and liver-related mortality in non-alcoholic fatty liver disease. J Hepatol. 2008;49:608-12.

21. Bonnet F, Gastaldelli A, Natali A, Roussel R, Petrie J, Tichet J, et al. Gammaglutamyltransferase, fatty liver index and hepatic insulin resistance are associated with incident hypertension in two longitudinal studies. J Hypertens. 2017;35:493-500.

22. Dan S, Banerjee I, Roy H, Roy S, Jana T, Dan S. Association between serum gamma-glutamyl transferase level and hypertension in Indian adults: a population based cross-sectional study. North Am J Med Sci. 2012;4:496.

23. Lee D-H, Ha M-H, Kim J-R, Gross M, Jacobs DR. Gamma-glutamyltransferase, alcohol, and blood pressure. A four year follow-up study. Ann Epidemiol. 2002;12:90-6.

24. Stranges S, Trevisan M, Dorn JM, Dmochowski J, Donahue RP. Body fat distribution, liver enzymes, and risk of hypertension: evidence from the Western New York study. Hypertension. 2005;46:1186-93.

25. Ali N, Rahman S, Islam S, Haque T, Molla NH, Sumon AH, et al. The relationship between serum uric acid and lipid profile in Bangladeshi adults. BMC Cardiovasc Disord. 2019;19:42

26. Ali N, Perveen R, Rahman S, Mahmood S, Rahman S, Islam S, et al. Prevalence of hyperuricemia and the relationship between serum uric acid and obesity: a study on Bangladeshi adults. PLoS One. 2018;13:e0206850

27. Haque T, Rahman S, Islam S, Molla NH, Ali N. Assessment of the relationship between serum uric acid and glucose levels in healthy, prediabetic and diabetic individuals. Diabetol Metab Syndr. 2019;11:49.

28. Schumann G, Klauke R. New IFCC reference procedures for the determination of catalytic activity concentrations of five enzymes in serum: preliminary upper reference limits obtained in hospitalized subjects. Clin Chim Acta. 2003:327:69-79.

29. Tietz NW, Shuey DF. Reference intervals for alkaline phosphatase activity determined by the IFCC and AACC reference methods. Clin Chem. 1986;32: 1593-4.
30. Chobanian AV. National heart, lung, and blood institute; national high blood pressure education program coordinating committee. seventh report of the joint national committee on prevention, detection, evaluation, and treatment of high blood pressure. Hypertension. 2003;42:1206-52.

31. Whelton PK, Carey RM, Aronow WS, Casey DE, Collins KJ, Dennison Himmelfarb C, et al. 2017 ACC/AHA/AAPA/ABC/ACPM/AGS/APhA/ASH/ ASPC/NMA/PCNA Guideline for the Prevention, Detection, Evaluation, and Management of High Blood Pressure in Adults: A Report of the American College of Cardiology/American Heart Association Task Force on Clinical Practice Guidelines. Hypertension. 2018;71 Available from: https://www. ahajournals.org/doi/10.1161/HYP.0000000000000065. [cited 2020 Feb 1].

32. Ha KH, Kim HC, Park S, Ihm SH, Lee HY. Gender differences in the association between serum $\gamma$-Glutamyltransferase and blood pressure change: a prospective community-based cohort study. J Korean Med Sci. 2014;29:1379-84.

33. Chun H, Park SK, Ryoo J-H. Association of serum $\mathrm{\gamma}$-glutamyltransferase level and incident prehypertension in Korean men. J Korean Med Sci. 2013;28: 1603-8.

34. Kawamoto R, Kohara K, Tabara Y, Kusunoki T, Otsuka N, Miki T. Association between serum gamma-glutamyl transferase level and prehypertension among community-dwelling men. Tohoku J Exp Med. 2008;216:213-21.

35. Shankar A, Li J. Association between serum gamma-glutamyltransferase level and prehypertension among US adults. Circ J. 2007;71:1567-72.

36. Zhu Y, Gong Y, Zhu R, Liu X, Sun Y, Wang Y, et al. Relationship between serum gamma-Glutamyltransferase levels and prehypertension in Chinese adults: the cardiometabolic risk in Chinese study. J Clin Hypertens. 2014;16: $760-5$.

37. López-Suárez A, Guerrero JMR, Elvira-González J, Beltrán-Robles M, CañasHormigo F, Bascuñana-Quirell A. Nonalcoholic fatty liver disease is associated with blood pressure in hypertensive and nonhypertensive individuals from the general population with normal levels of alanine aminotransferase. Eur J Gastroenterol Hepatol. 2011;23:1011-7.

38. Musso G, Gambino R, De Michieli F, Durazzo M, Pagano G, Cassader M. Adiponectin gene polymorphisms modulate acute adiponectin response to dietary fat: possible pathogenetic role in NASH. Hepatol Baltim Md. 2008;47: 1167-77.

39. Preetha S. Estimation of liver function test in hypertension patients. J Pharm Sci Res. 2016;8:869

40. Shimizu Y, Nakazato M, Sekita T, Kadota K, Yamasaki H, Takamura N, et al. Association between alkaline phosphatase and hypertension in a rural Japanese population: the Nagasaki Islands study. J Physiol Anthropol. 2013;32:10.

41. Aneni EC, Oni ET, Martin SS, Blaha MJ, Agatston AS, Feldman T, et al. Blood pressure is associated with the presence and severity of nonalcoholic fatty liver disease across the spectrum of cardiometabolic risk. J Hypertens. 2015; 33:1207-14

42. Sung K-C, Wild SH, Byrne CD. Development of new fatty liver, or resolution of existing fatty liver, over five years of follow-up, and risk of incident hypertension. J Hepatol. 2014;60:1040-5.

43. Lee $D-H$, Blomhoff $R$, Jacobs DR. Review is serum gamma glutamyltransferase a marker of oxidative stress? Free Radic Res. 2004;38: 535-9.

44. Touyz RM. Reactive oxygen species, vascular oxidative stress, and redox signaling in hypertension: what is the clinical significance? Hypertension. 2004:44:248-52.

45. Eslami S, Sahebkar A. Glutathione-S-transferase M1 and T1 null genotypes are associated with hypertension risk: a systematic review and meta-analysis of 12 studies. Curr Hypertens Rep. 2014;16:432.

46. Mansego ML, Solar GDM, Alonso MP, Martínez F, Sáez GT, Escudero JCM, et al. Polymorphisms of antioxidant enzymes, blood pressure and risk of hypertension. J Hypertens. 2011;29:492-500.

\section{Publisher's Note}

Springer Nature remains neutral with regard to jurisdictional claims in published maps and institutional affiliations. 